\title{
ULTRASOUND ENHANCED THROMBOLYSIS FOR STROKE
}

\author{
Andrei V. Alexandrov
}

Therapeutic Neurosonology Laboratory and the Stroke Research Program, Barrow Neurologic Institute, Phoenix, AZ, USA

\begin{abstract}
SUMMARY - Spontaneous arterial recanalization occurs at a rate of $6 \%$ per hour, and it can be doubled with intravenous tissue plasminogen activator (TPA) therapy since early dramatic clinical improvement, a substitute for early thrombus break-up, occurs in TPA treated patients. TPA activity can be enhanced with ultrasound including $2 \mathrm{MHz}$ transcranial Doppler (TCD). TCD identifies residual blood flow signals around thrombi, and, by delivering mechanical pressure waves, exposes more thrombus surface to circulating TPA. In the CLOTBUST trial, the dramatic clinical recovery from stroke coupled with complete recanalization within 2 hours after TPA bolus occurred in $25 \%$ of patients treated with TPA+TCD compared to $8 \%$ of those that received TPA alone $(p=0.02)$. Complete clearance of a thrombus and dramatic recovery of brain function during treatment are feasible goals for ultrasoundenhanced thrombolysis that can lead to sustained recovery. An early boost in brain perfusion seen in the CLOTBUST target group resulted in a trend of $13 \%$ more patients achieving favorable outcome at 3 months, thus providing the rationale for a pivotal trial. The ability of TPA to break up thrombi can be further enhanced with harmless diagnostic ultrasound contrast agents. Current ongoing clinical trials include phase II studies of $2 \mathrm{MHz}$ TCD with ultrasound contrast agents, or microbubbles: TCD+TPA+Levovist; TCD+TPA+MRX nano-platform $\left(\mathrm{C}_{3} \mathrm{~F}_{8} \mathrm{ImaRx}\right)$. Intra-arterial ultrasoundenhanced TPA delivery is tested in the Interventional Management of Stroke (IMS) clinical trial using 1.7-2.1 MHz pulsed wave ultrasound catheter (EKOS). Dose escalation studies of microbubbles, ultrasound exposure and the development of an operator independent ultrasound device are currently underway.
\end{abstract}

Key words: Cerebrovascular accident - therapy; Thrombolytic therapy; Ultrasonography, Doppler, transcranial therapy; Fibrinolytic agents - therapeutic use; Thrombolysis - outcomes

\section{Introduction}

In a recent review of observational studies and acute stroke clinical trials, spontaneous arterial recanalization was observed in $17 \%$ of patients undergoing angiography between 6 to 8 hours of stroke onset ${ }^{1}$. In addition, spontaneous arterial recanalization was estimated to occur at a rate of $6 \%$ per hour in patients with the middle cerebral artery occlusion who did not receive thrombolytic drugs ${ }^{2}$.

The pilot clinical studies of thrombolysis for ischemic stroke did not document dramatic, or "on the table" clinical recovery during treatment ${ }^{3-5}$. Subsequent pivotal

Correspondence to: Andrei $V$. Alexandrov, $M D$, Therapeutic Neurosonology Laboratory and the Stroke Research Program, Barrow Neurologic Institute, Phoenix, AZ, USA

E-mail: avalexandrov@att.net

Received September 12, 2006, October, 2006 trials of TPA have not reported any differences between the groups at 2 and 24 hours post treatment in the prespecified end-points ${ }^{6-9}$. However, a post-hoc analysis of the NINDS trial ${ }^{10}$ showed that by 24 hours, $27 \%$ of TPAtreated patients improved by $\geq 10$ points on the National Institutes of Health Stroke Scale (NIHSS) or resolved their neurological deficit completely compared to $12 \%$ in the placebo group $(\mathrm{p}=0.002)$. Broderick et al. found the total NIHSS score of $0-2$ points at 24 hours to be the most sensitive measure of successful treatment with iv. TPA predicting good outcome at 90 days ${ }^{11}$. This early clinical recovery can be indicative of early arterial recanalization and nutritious reperfusion. However, the proportion of treated patients experiencing this dramatic recovery is relatively low.

Early clinical improvement after stroke usually occurs after arterial recanalization ${ }^{12-15}$. Recanalization was 
measured in a pilot angiographic study of TPA therapy for stroke but not in the NINDS rt-PA Stroke Study or European Cooperative Stroke Studies ${ }^{6-9}$. Since early recanalization can lead to dramatic recovery ${ }^{12-15}$, any additional enhancement of TPA-associated thrombus dissolution, with increased early arterial recanalization rates should, in theory, produce even higher early dramatic recovery rates among patients with ischemic stroke.

The rationale for use of a mechanical pressure wave, i.e. ultrasound, to enhance thrombolysis was first observed and recognized in the $1970 \mathrm{~s}^{16}$ and $1980 \mathrm{~s}^{17}$, and confirmed by several investigators using various experimental models ${ }^{18-21}$. A simple analogy is that if you put sugar in a cup of water, sugar promptly goes down to the bottom, and it will take some time for it to dissolve completely since there is no water motion. However, if you stir water with a spoon, the sugar dissolves much faster.
Ultrasound, as its pressure wave propagates through the tissues, induces fluid motion and facilitates delivery of TPA to reach the binding sites on clot bound fibrin. Researchers have proposed three different mechanisms of ultrasound-enhanced thrombolysis: (a) fluid streaming around clot surface; (b) disaggregation of non cross-linked fibrin fibers; and (c) creating more binding sites for TPA without heating or cavitation ${ }^{23,24}$ (Fig. 1). Low kilohertz $(\mathrm{kHz})$ frequencies are better at potentiating TPA effects than are higher frequencies ${ }^{25}$. However, these systems are not available for clinical practice due to safety concerns and inability to image vasculature with this frequency/wavelength range. Fortunately, the carrier frequency range that is safely used for diagnostic ultrasound examinations, 1-2.2 MHz, can enhance TPA-induced thrombus dissolution ${ }^{23,24}$, although the optimal frequency has not been determined.

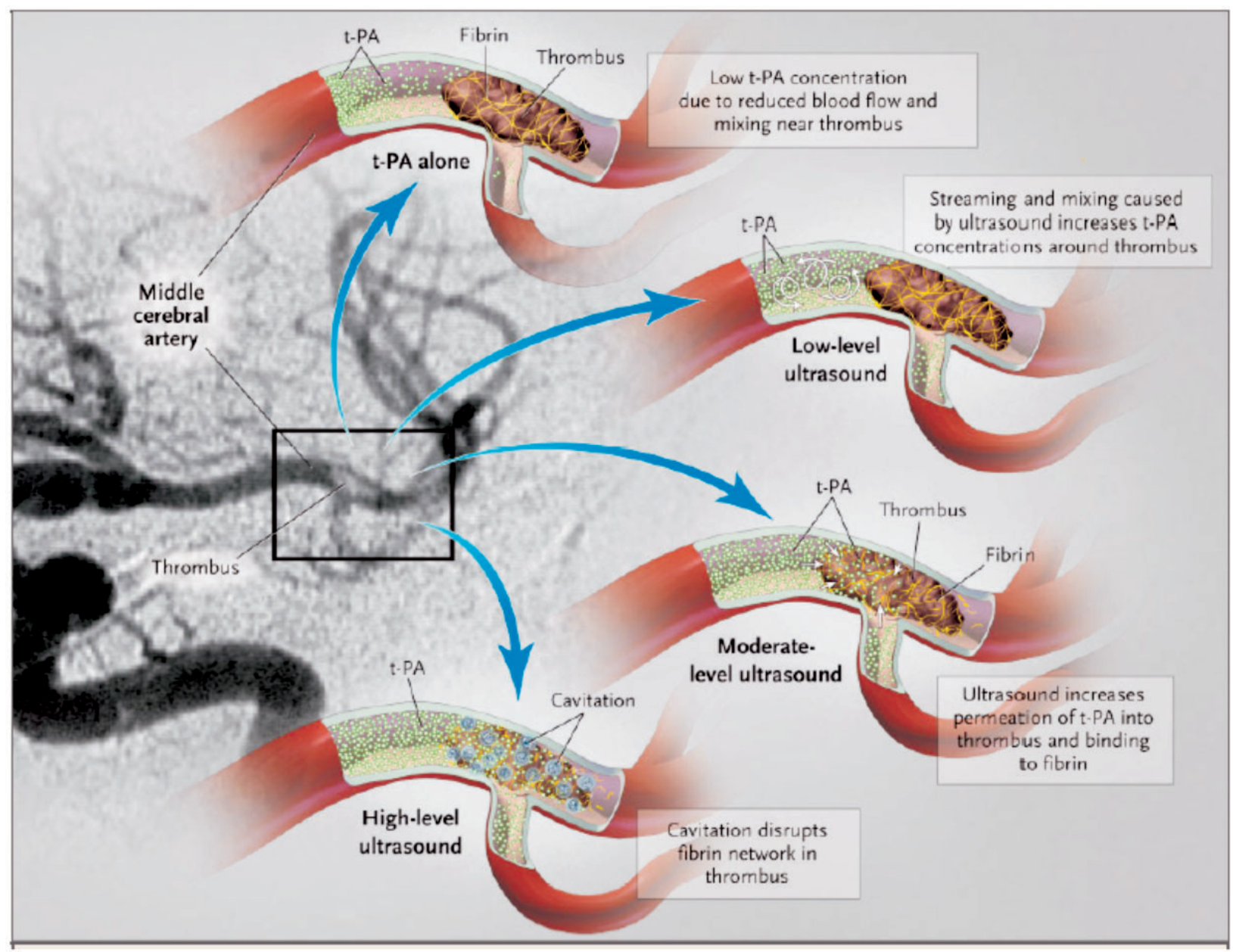

Fig. 1. Potential mechanisms of ultrasound-enhanced thrombolysis (reproduced with permission from Polak JF. N Engl J Med 2004;351:2154-5). 
Fig. 2. Abnormal arterial residual flow signals sampled from thrombus-residual flow interface (arrowes) at the site of an acute thromboembolic MCA occlusion (reprinted with permission from Alexandrov AV. Ultrasound identification and lysis of clots. Stroke 2004;35(Suppl 1):2722-5).

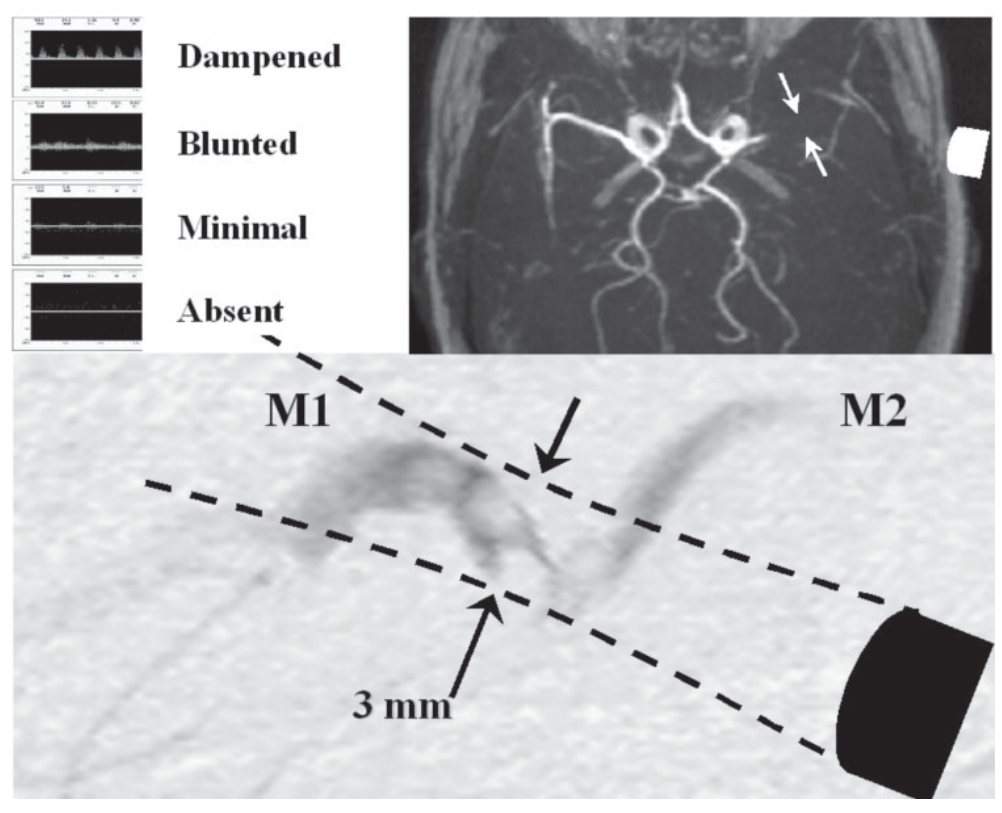

Portable diagnostic $2 \mathrm{MHz}$ TCD equipment can be used in the emergency room to rapidly identify the presence and location of an arterial occlusion, or lesions amenable to intervention ${ }^{26}$, and to continuously monitor TPA infusion in acute ischemic stroke patients ${ }^{27}$. With prior training and experience in interpretation of TCD, this test, particularly in combination with urgent carotid/vertebral duplex scanning, can yield high degrees of accuracy for detection and localization of arterial occlusion as well as assessment of recanalization at the bedside ${ }^{26,27}$.

The diagnosis of an acute arterial obstruction to flow and subsequent recanalization depends on finding abnormal residual flow and signs of compensatory flow diversion ${ }^{26}$. Once abnormal residual flow signals are identified, an ultrasound beam can be steadily focused at the presumed intracranial thrombus location (Fig. 2), and arterial recanalization can be monitored in real time ${ }^{25}$. When intravenous TPA infusion was continuously monitored with $2 \mathrm{MHz} \mathrm{TCD}^{27}$, we observed early recanalization and dramatic recovery rates higher than expected from pivotal trials ${ }^{3}$. This non-randomized study of patients treated with different TPA dose ${ }^{27}$ suggested a potential therapeutic effect of TCD, which led to a prospective randomized pilot clinical trial.

\section{The CLOTBUST Trial}

The CLOTBUST (Combined Lysis of Thrombus in Brain ischemia using transcranial Ultrasound and Sys- temic TPA) was a phase II clinical randomized multicenter international pilot trial with centers in Houston, Barcelona, Edmonton, and Calgary ${ }^{28}$. It had pre-specified safety and signal of efficacy end-points and a predetermined sample size of 63 patients per group ${ }^{28}$. All enrolled patients had an acute ischemic stroke, and were treated with a standard $0.9 \mathrm{mg} / \mathrm{kg}$ dose of intravenous TPA therapy within 3 hours of symptom onset. All patients also had MCA occlusions on pretreatment TCD. They were randomized (1:1) to continuous TCD monitoring (target) or placebo monitoring (control). The primary safety end-point was symptomatic brain hemorrhage (sICH) causing worsening of the neurological deficit by 4 or more NIHSS points. The primary combined clinical outcome end-point was complete recanalization on TCD or dramatic clinical recovery, by the total NIHSS score $\leq 3$ points or improvement by $\geq 10$ NIHSS points within 2 hours after TPA bolus. Clinical investigators were blinded to group assignment (active or sham monitoring) done by sonographers.

All projected 126 patients received TPA and were randomized 1:1 to target (median pretreatment NIHSS 16 points) or control (NIHSS 17 points). Age, occlusion location on TCD and time to TPA bolus were similar between the groups. sICH occurred in $4.8 \%$ of target and $4.8 \%$ of control patients. Primary end-point was achieved by 31 (49\%, target) vs. 19 (30\%, control) $(\mathrm{p}=0.03)$ patients. At 3 months, $42 \%$ target and $29 \%$ control patients achieved favorable outcomes (mRS 0-1 points) $(\mathrm{p}=\mathrm{NS})$ (Fig. 3). This trend in favorable clini- 
cal outcomes supports the feasibility of a pivotal phase III clinical trial that, with 274 patients per group, would be properly powered ( $80 \%$ or $90 \%$ ?) to detect this difference in outcomes at 3 months ${ }^{28}$.

\section{Other Clinical Trials}

Transcranial duplex technology was recently tested in a smaller randomized clinical trial ${ }^{29}$. Duplex transducers are different from the ones used in CLOTBUST since they generate multiple small beams at dual emitting frequencies, one for Doppler and one for gray scale imaging. One of the major limitations of this technology is that there are no reliable head frames for transducer fixation, and most studies are to be carried out handheld.

Eggers et al. evaluated 25 patients (11 target TPA+ duplex monitoring, 14 controls TPA alone) and reported a trend in the target group towards higher recanalization rates, more hemorrhagic transformations, and better outcomes at 3 months compared to patients who received TPA alone ${ }^{29}$. This study did not have a predetermined sample size, and the results may have been affected by a small number of patients enrolled. More studies are needed to evaluate the potential of transcranial duplex technology to enhance thrombolysis.
The same group and others ${ }^{30-32}$ have reported provocative findings that patients who are not eligible for systemic TPA therapy may potentially benefit from continuous monitoring with ultrasound alone since, hypothetically, ultrasound may help facilitate the endogenous thrombolytic process that leads to spontaneous recanalization in acute stroke patients. It is unclear if only partial recanalization can be induced by ultrasound alone, and if this exposure would result in a significant difference at 3 months justifying a large clinical trial.

Therapeutic, i.e. non-imaging ultrasound has been tested in the TRanscranial low-frequency UltrasoundMediated thrombolysis in Brain Ischemia (TRUMBI) trial $^{33}$. Patient enrollment was stratified by time of symptom onset, 0-3 hours and 3-6 hours. In addition, the investigators used a very low $\mathrm{KHz}$ system $(<40 \mathrm{KHz})$ that produced intolerable tinnitus and was withdrawn from clinical testing (Daffertshofer M, unpublished data). It was replaced by a mid-KHz system operating at $300 \mathrm{KHz}$. Brain hemorrhage was defined by findings on both CT and MRI scans mandated by the trial. The trial was terminated after 26 patients were enrolled with a $36 \%$ rate of symptomatic hemorrhage in the target group and no signal of efficacy on early recanalization or clinical outcomes at 3 months ${ }^{34}$. The trial demonstrated bioeffects of mid-KHz ultrasound that promoted bleeding,
TPA bolus NIHSS 12

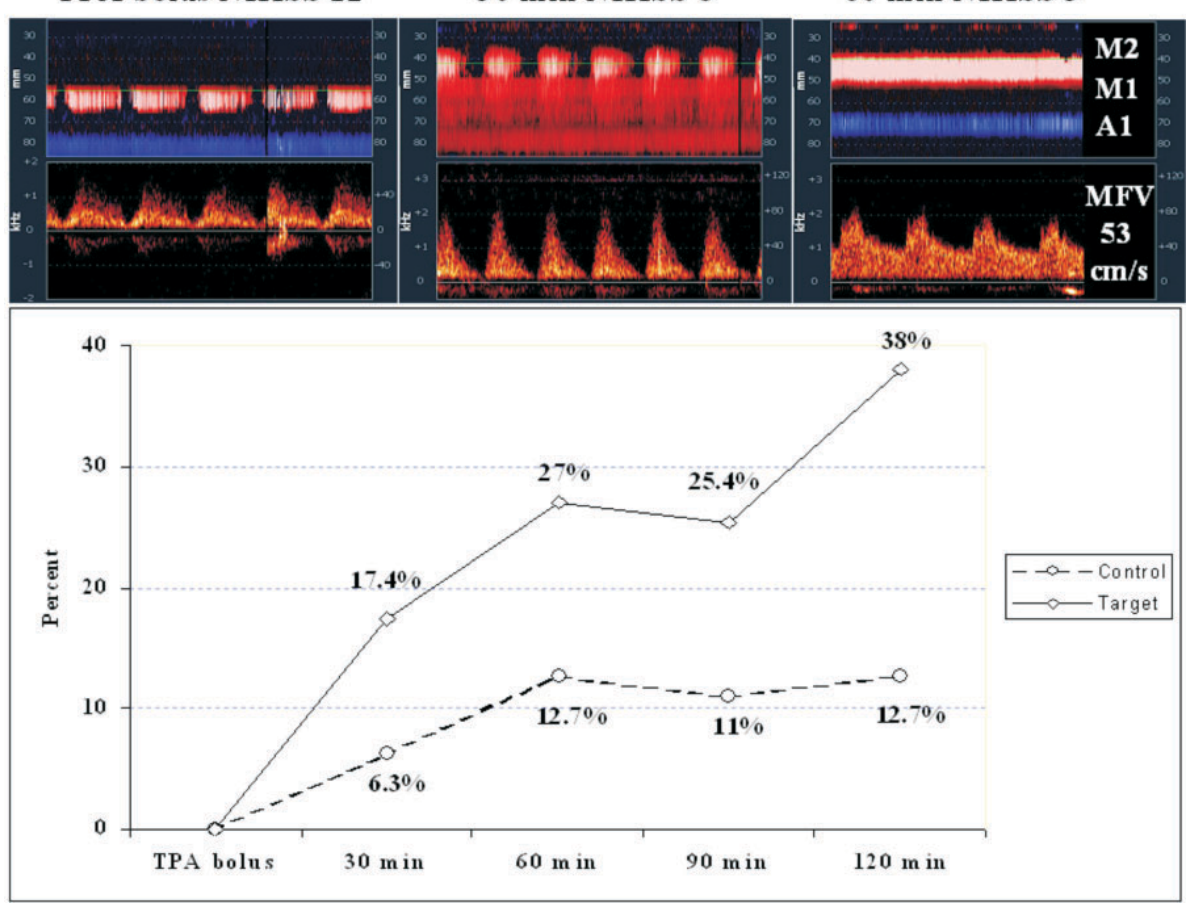

Fig. 3. Upper panel: complete $M C A$ recanalization on powermotion TCD and dramatic clinical recovery within 60 minutes of TPA bolus; lower panel: early recanalization rates with ultrasound-enhanced TPA therapy for acute thromboembolic MCA occlusion in the CLOTBUST trial (reprinted with permission from $\mathrm{Al}$ exandrov AV. Ultrasound identification and lysis of clots. Stroke 2004;35(Suppl 1):2722-5). 
including brain areas not affected by ische-mia ${ }^{33}$. However, the results were unclear as to the exact timing of the brain hemorrhages. Further research should determine if "standing" pressure waves and endothelial disruption may cause these adverse effects. If confirmed in in vivo models, this will have implications on the design of future KHz-based systems.

Ultrasound transducers have also been incorporated into a catheter for intra-arterial delivery of a thrombolytic drug (EKOS Corporation). This intra-arterial device uses 1.7-2.1 MHz pulsed wave ultrasound with the emitting power of $400 \mathrm{~mW}$, parameters similar to extracranially applied transcranial Doppler. The EKOS catheter is now being tested in phase II-III Interventional Management of Stroke (IMS) trials ${ }^{35}$.

\section{Future Directions}

Different experimental strategies are being tested in an extended time window for acute stroke treatment. Continuous, short duration exposure to ultrasound may find its application while the patient may be receiving other agents such as glycoprotein IIb-IIIa receptor antagonists, direct thrombin inhibitors or is awaiting an endovascular recanalization procedure (pharmacologic or mechanical).

Ultrasound-enhanced thrombolysis can be further amplified by adding gaseous microbubbles ${ }^{36-39}$. Microbubbles, safe ultrasound contrast agents, are micronsized lipid shells that when exposed to ultrasound, expand and produce stable cavitation with stronger reflected echoes. This is used to generate ultrasound images with better resolution. At the same time, microbubbles agitate fluid where they are released by ultrasound and this is useful in drug delivery and mechanical "grinding" of a thrombus. In fact, microbubbles have their own ability to lyse thrombi without a lytic drug ${ }^{39}$.

Several studies have been reported with different types of commercially available microbubbles ${ }^{40}$. Molina et al. report on the largest study to date that compared the CLOTBUST target arm to the CLOTBUST target insonation protocol combined with Levovist air microbubbles (Schering AG) ${ }^{38}$. Investigators demonstrated that at 2 hours after TPA bolus the TPA+TCD + Levovist group achieved a 55\% sustained recanalization rate compared to $38 \%$ in the TPA+TCD group of the CLOTBUST trial. An international multi-center study of a new and more stable $\mathrm{C}_{3} \mathrm{~F}_{8}$ microbubble, MRX 815 nano-platform, is underway ${ }^{41}$.
One technical problem that may limit the development of ultrasound and microbubble assisted stroke therapies is the need of an experienced sonographer to find intracranial thrombus, and expose its surface to residual flow in order to lodge more TPA and agitate stagnant flow. Personnel with these skills are lacking in most emergency centers. Future studies will focus on finding the optimal frequency and duration of exposure to ultrasound $^{42}$ as well as the development of an operatorindependent ultrasound device that can be used by existing medical personnel regardless of their experience in diagnostic ultrasound.

\section{Acknowledgment}

CLOTBUST studies are Investigator Sponsored Clinical Trials (MRX-815 Nano-platform, ImaRx Therapeutics, Inc, A2207s, Genentech, Inc, NIH 1 K23 NS02229-01 grant to Dr Alexandrov). Study sites include Houston, Barcelona, Phoenix, Heidelberg, Charlotte, Calgary, and Edmonton.

\section{References}

1. KASSEM-MOUSSA H, GRAFFAGNINO C. Nonocclusion and spontaneous recanalization rates in acute ischemic stroke: a review of cerebral angiography studies. Arch Neurol 2002:59: 1870-3.

2. ALEXANDROV AV, BLADIN GF, NORRIS JW. Intracranial blood flow velocities in acute ischemic stroke. Stroke 1994;25: 1378-83.

3. del ZOPPO GJ, POECK K, PESSIN MS, WOLPERT SM, FURLAN AJ, FERBERT A, ALBERTS MJ, ZIVIN JA, WECHSLER L, BUSSE O, GREENLEE R, BRASS L, MOHR JP, FELDMANN E, HACKE W, KASE CS, BILLER J, GRESS D, OTIS SM. Recombinant tissue plasminogen activator in acute thrombotic and embolic stroke. Ann Neurol 1992;32:78-86.

4. BROTT TG, HALEY EC, LEVY DE et al. Urgent therapy for stroke. Part I pilot study of tissue plasminogen activator administered within 90 minutes. Stroke 1992;23:632-40.

5. HALEY EC, LEVY DE, BROTT TG et al. Urgent therapy for stroke. Part II pilot study of tissue plasminogen activator administered 91-180 minutes from onset. Stroke 1992;23:641-5.

6. The National Institutes of Neurological Disorders and Stroke rt-PA Stroke Study Group. Tissue plasminogen activator for acute ischemic stroke. N Engl J Med 1995;333:1581-7.

7. HACKE W, KASTE M, FIESCHI C et al. Intravenous thrombolysis with recombinant tissue plasminogen activator for acute ischemic stroke: the European Cooperative Acute Stroke Study. JAMA 1995;274:1017-25.

8. HACKE W, KASTE M, FIESCHI C et al. Randomised doubleblind placebo-controlled trial of thrombolytic therapy with intravenous alteplase in acute ischemic stroke (ECASS II): 
Second European-Australasian Acute Stroke Study Investigators. Lancet 1998;352:1245-51.

9. HACKE W, DONNAN G, FIESGHI C, KASTE M, von KUMMER R, BRODERICK JP, BROTT T, FRANKEL M, GROTTA JC, HALEY EC Jr, KWIATKOWSKI T, LEVINE SR, LEWANDOWSKI C, LU M, LYDEN P, MARLER JR, PATEL S, TILLEY BC, ALBERS G, BLUHMKI E, WILHELM M, HAMILTON S; ATLANTIS Trials Investigators; ECASS Trials Investigators; NINDS rt-PA Study Group Investigators. Association of outcome with early stroke treatment: pooled analysis of ATLANTIS, ECASS, and NINDS rt-PA stroke trials. Lancet 2004;363:768-74.

10. HALEY EC, LEWANDOWSKI C, TILleY BC. Myths regarding NINDS rt-PA Stroke Trial: setting the record straight. Ann Emerg Med 1997; 30:676-82.

11. BRODERICK JP, LU M, KOTHARI R, LEVINE SR, LYDEN PD, HALEY EC, BROTT TG, GROTTA JC, TILLEY BC, MARLER JR, FRANKEL M. Finding of the most powerful measures of the effectiveness of tissue plasminogen activator in the NINDS tPA Stroke trial. Stroke 2000;31:2335-41.

12. DEMCHUK AM, FELBERG RA, ALEXANDROV AV. Clinical recovery from acute ischemic stroke after early reperfusion of the brain with intravenous thrombolysis. N Engl J Med 1999;340:894-5.

13. GROTTA JC, ALEXANDROV AV. TPA-associated reperfusion in acute ischemic stroke demonstrated by SPECT. Stroke 1998:29:429-32.

14. HEISS W-D, GROND M, THIEL A, von STOCKHAUSEN HM, RUDOLF J, GHAEMI M, LOTTGEN J, STENZEL C, PAWLIK G. Tissue at risk of infarction rescued by early reperfusion: a positron emission tomography study in systemic recombinant tissue plasminogen activator thrombolysis of acute stroke. J Cereb Blood Flow Metab 1998;18:1298-307.

15. RINGELSTEIN EB, BINIEK R, WEILLER C, AMMELING B, NOLTE PN, THRON A. Type and extent of hemispheric brain infarctions and clinical outcome in early and delayed middle cerebral artery recanalization. Neurology 1992;42:289-98.

16. TRUBESTEIN R, BERNARD HR, ETZEL F, SOBBE A, CREMER A, STUMPFF U. Thrombolysis by ultrasound. Clin Sci Mol Med 1976;51:697-8.

17. TACHIBANA K, TACHIBANA $S$. Ultrasonic vibration for boosting fibrinolytic effects of urokinase in vivo. Thromb Haemost 1981;46:211. (abstract)

18. LAUER CG, BURGE R, TANG DB, BASS BG, GOMEZ ER, ALVING BM. Effect of ultrasound on tissue-type plasminogen activator-induced thrombolysis. Circulation 1992;86:1257-64.

19. KIMURA M, IIJIMA S. KOBAYASHI K, FURUHATA H. Evaluation of the thrombolytic effect of tissue-type plasminogen activator with ultrasound irradiation: in vitro experiment involving assay of the fibrin degradation products from the clot. Biol Pharm Bull 1994;17:126-30.

20. AKIYAMA M, ISHIBASHI T, YAMADA T, FURUHATA H. Low-frequency ultrasound penetrates the cranium and enhances thrombolysis in vitro. Neurosurgery 1998;43:828-32.
21. SUCHKOVA V, SIDDIQI FN, CARSTENSEN EL, DALECKI D, CHILD S, FRANCIS CW. Enhancement of fibrinolysis with 40-kHz ultrasound. Circulation 1998;98:1030-5.

22. BEHRENS S, DAFFERTSHOFFER M, SPIEGEL D, HENNERICI M. Low-frequency, low-intensity ultrasound accelerates thrombolysis through the skull. Ultrasound Med Biol 1999;25:269-73.

23. BEHRENS S, SPENGOS K, DAFFERTSHOFER M, SCHROECK H, DEMPFLE CE, HENNERICI M. Transcranial ultrasound-improved thrombolysis: diagnostic $v$ s. therapeutic ultrasound. Ultrasound Med Biol 2001;27:1683-9.

24. BLINC A, FRANCIS CW, TRUDNOWSKI JL, CARSTENSEN EL. Characterization of ultrasound-potentiated fibrinolysis in vitro. Blood 1993;81:2636-43.

25. SPENGOS K, BEHRENS S, DAFFERTSHOFER M, DEMPFLE CE, HENNERICI M. Acceleration of thrombolysis with ultrasound through the cranium in a flow model. Ultrasound Med Biol 2000;26:889-95.

26. CHERNYSHEV OY, GARAMI Z, CALLEJA S, SONG J, CAMPBELL MS, NOSER EA, SHALTONI H, GHEN GI, IGUCHI Y, GROTTA JC, ALEXANDROV AV. The yield and accuracy of urgent combined carotid-transcranial ultrasound testing in acute cerebral ischemia. Stroke 2005;36:32-7.

27. ALEXANDROV AV, DEMCHUK AM, FELBERG RA, CHRISTOU I, BARBER PA, BURGIN WS, MALKOFF M, WOJNER AW, GROTTA JC. High rate of complete recanalization and dramatic clinical recovery during TPA infusion when continuously monitored by $2 \mathrm{MHz}$ transcranial Doppler monitoring. Stroke 2000:31:610-4.

28. ALEXANDROV AV, MOLINA CA, GROTTA JC, GARAMI $Z$, FORD SR, ALVAREZ-SABIN J, MONTANER J, SAQQUR M, DEMCHUK AM, MOYE LA, HILL MD, WOJNER AW. Ultrasound-enhanced systemic thrombolysis for acute ischemic stroke. N Engl J Med 2004;351:2170-8.

29. EGGERS J, KOCH B, MEYER K, KONIG I, SEIDEL G. Effect of ultrasound on thrombolysis of middle cerebral artery occlusion. Ann Neurol 2003;53:797-800.

30. EGGERS J, SEIDEL G, KOCH B, KONIG IR. Sonothrombolysis in acute ischemic stroke for patients ineligible for rt-PA. Neurology 2005;64:1052-4.

31. CINTAS P, Le TRAON AP, LARRUE V. High rate of recanalization of middle cerebral artery occlusion during $2-\mathrm{MHz}$ transcranial color-coded Doppler continuous monitoring without thrombolytic drug. Stroke 2002;33:626-8.

32. SKOLOUDIK D, BAR M, HRADILEK P, VACLAVIK D, SKODA O. Safety and efficacy of thrombotripsy - acceleration of thrombolysis by TCCS. CD-ROM Proceedings of the NSRG 2003 Meeting, Germany.

33. DAFFERTSHOFFER M, HENNERICI M. Ultrasound in the treatment of ischaemic stroke. Lancet Neurology 2003;2:283-90.

34. DAFFERTSHOFER M, GASS A, RINGLEB P, SITZER M, SLIWKA U, ELS T, SEDLACZEK O, KOROSHETZ W, HENNERICI MG. Transcranial low-frequency ultrasound- 
mediated thrombolysis in brain ischemia: increased risk of hemorrhage with combined ultrasound and tissue plasminogen activator. Stroke 2005;36:1441-6.

35. The IMS Study Investigators. Combined intravenous and intraarterial recanalization for acute ischemic stroke: The Interventional Management of Stroke Study. Stroke 2004;35: 904-12.

36. UNGER EC, PORTER T, CULP W, LABELL R, MATSUNAGA T, ZUTSHI R. Therapeutic applications of lipid-coated microbubbles. Adv Drug Deliv Rev 2004;56:1291-314.

37. CULP WC, PORTER TR, McCOWAN TC, ROBERTSON PK, JAMES CA, MATCHETT WJ, MOURSI M. Microbubbleaugmented ultrasound declotting of thrombosed arteriovenous dialysis grafts in dogs. J Vasc Interv Radiol 2003;14:343-7.

38. MOLINA CA, RIBO M, ARENILLAS J, RUBIERA M, MONTANER J, SANTAMARINA E, HUERTAS R, DEALGADO P, PURROY F, ALVAREZ-SABIN J. Microbubbles administration accelerates clot lysis during continuous $2 \mathrm{MHz}$ ultrasound monitoring in stroke patients treated with intra-venous tPA. Stroke 2005;36:419. (abstract).

39. GULP WC, PORTER TR, LOWERY J, XIE F, ROBERSON PK, MARKY L. Intracranial clot lysis with intravenous microbubbles and transcranial ultrasound in swine. Stroke 2004;35:2407-11.

40. MARTINA AD, MEYER-WIETHE K, ALLEMANN E, SEIDEL G. Ultrasound contrast agents for brain perfusion imaging and ischemic stroke therapy. J Neuroimaging 2005; 15:217-32.

41. http://www.imarx.com/ImaRx/thera4_0

42. SLOAN MA, ALEXANDROV AV, TEGELER CH, SPENCER MP, GAPLAN LR, FELDMANN E, WECHSLER LR, NEWELL DW, GOMEZ CR, BABIKIAN VL, LEFKOWITZ D, GOLDMAN RS, ARMON C, HSU CY, GOODIN DS. Assessment: transcranial Doppler ultrasonography: report of the Therapeutics and Technology Assessment Subcommittee of the American Academy of Neurology. Neurology 2004;62:1468-81.

Sažetak

\title{
ULTRAZVUKOM POJAČANA TROMBOLIZA KOD MOŽDANOG UDARA
}

\author{
A.V. Alexandrov
}

Spontana arterijska rekanalizacija odvija se po stopi od $6 \%$ na sat, što se može udvostručiti pomoću terapije intravenskim aktivatorom tkivnog plazminogena (TPA), jer u bolesnika liječenih pomoću TPA dolazi do ranog dramatičnog kliničkog poboljšanja kao nadomjestak za rano razbijanje tromba. Aktivnost TPA može se pojačati ultrazvukom uključujući transkranijski Doppler (TCD) od 2 MHz. TCD identificira signale ostatnog krvnog protoka oko trombusa te kroz stvaranje valova mehaničkog tlaka izlaže veću površinu tromba cirkulirajućem TPA. U pokusu CLOTBUST je značajan klinički oporavak od moždanog udara uz potpunu rekanalizaciju unutar 2 sata od davanja bolusa TPA nastupio u 25\% bolesnika liječenih pomoću TPA+TCD, u usporedbi s $8 \%$ bolesnika koji su primili samo TPA $(p=0,02)$. Potpuno uklanjanje tromba i značajan oporavak moždane funkcije tijekom liječenja izvedivi su ciljevi ultrazvukom pojačane trombolize koji mogu dovesti do održivog oporavka. Kao rezultat ranog stimuliranja moždane perfuzije, zabilježenog u ciljnoj skupini studije CLOTBUST, 13\% više bolesnika postiglo je povoljan ishod nakon 3 mjeseca, pruživši time razlog za ključni pokus. Sposobnost TPA da razbije trombe može se dodatno pojačati neškodljivim dijagnostičkim kontrastnim sredstvima za ultrazvuk. Upravo su u tijeku kliničke studije 2. faze s kontrastnim sredstvima za ultrazvuk od $2 \mathrm{MHz}$ ili mikrokuglicama TCD+TPA+Levovist; TCD+TPA+MRX nano-platforma $\left(\mathrm{C}_{3} \mathrm{~F}_{8}\right.$ ImaRx $)$. Intraarterijsko davanje TPA pojačano ultrazvukom ispituje se u kliničkom pokusu Interventional Management of Stroke (IMS) uz primjenu ultrazvučnog katetera pulsnih valova od 1,7-2,1 MHz (EKOS). U tijeku su studije pojačavanja mikrokuglica, izlaganja ultrazvuku, kao i razvoj ultrazvučnog uređaja neovisnog o operatoru.

Ključne riječi: Cerebrovaskularni incident - terapija; Trombolitična terapïa; Ultrazvuk, Doppler, transkranijski - terapija; Fibrinolitična sredstva - terapijska primjena; Tromboliza - ishodi 